\title{
Transfusion-Associated Immunomodulation: Experimental Facts and Clinical Reality - New Perspectives
}

\author{
Hans Jørgen Nielsen \\ Department of Surgical Gastroenterology, Hvidovre University Hospital, Denmark
}

\author{
Key Words \\ Blood transfusion - Infectious complications . \\ Cancer recurrence $\cdot$ Immunomodulation - Leukofiltration . \\ Gene polymorphism
}

\section{Summary}

Blood component transfusion may be required in association with emergency and chronic disease to improve hemodynamics and tissue oxygenation. Due to the risk of microbial transfection from donor to recipient, the blood is undergoing vigorous testing to improve safety. It is well known, however, that blood component transfusion may lead to certain acute side effects with a frequency of $0.5-2 \%$ depending on the specific component transfused. In addition, homologous blood component transfusion seems to be associated with increased frequency of bacterial infectious complication after operation in a variety of diseases. If patients have been operated on for malignant diseases, emerging evidence has accumulated that suggests a combination of blood component transfusion, postoperative bacterial infectious complications and subsequent poor longterm survival even in patients who have been curatively resected. The mechanisms leading to such side effects are not known in detail, but bioactive substance accumulation during preparation and storage may play an important role. Such substances may also explain why side effects are also observed after autologous blood transfusion. Institution of universal leukofiltration in most European countries has led to improvement in patient treatment, with reduction of a variety of side effects. Future research should be focused on patient genetic polymorphisms that may play a role in the development of side effects to blood component transfusion.

\author{
Schlüsselwörter \\ Bluttransfusion - Infektiöse Komplikationen - Tumorrezidiv . \\ Immunmodulation · Leukofiltration · Genpolymorphismus
}

\section{Zusammenfassung}

In der akuten und chronischen Krankheitssituation kann eine Blutkomponententransfusion erforderlich sein, um die Hämodynamik und die Gewebeoxygenierung zu verbessern. Um eine mikrobielle Transfektion vom Spender zum Empfänger zu vermeiden und die Transfusionssicherheit zu verbessern, wird gespendetes Blut einer intensiven Prüfung unterzogen. Allerdings führt die Blutkomponententransfusion in $0,5-2 \%$ der Fälle - abhängig von der transfundierten Komponente - zu akuten Nebenwirkungen. Darüber hinaus scheint die homologe Blutkomponententransfusion bei einer Reihe von Erkrankungen die Häufigkeit des Auftretens bakterieller infektiöser Komplikationen nach Operation zu erhöhen. Bei Patienten, die wegen maligner Erkrankungen operiert werden, gibt es zunehmend mehr Hinweise für eine Verbindung zwischen Blutkomponententransfusion, postoperativen bakteriellen, infektiösen Komplikationen und einem draus resultierenden schlechten Langzeitüberleben, sogar bei solchen Patienten, bei denen eine kurative Resektion durchgeführt werden konnte. Die Mechanismen, die diesen Nebenwirkungen zugrunde liegen, sind im Detail noch unbekannt, aber die Akkumulation von bioaktiven Substanzen während der Präparation und Lagerung spielt möglicherweise eine bedeutende Rolle. Derartige Substanzen könnten auch erklären, warum die Nebenwirkungen auch nach autologer Bluttransfusion auftreten. Die Einführung der Leukofiltration hat in den meisten europäischen Ländern durch die Reduzierung einer Reihe von Nebenwirkungen zu einer Verbesserung der Patientenbehandlung geführt. Zukünftige Untersuchungen sollten genetische Polymorphismen der Patienten und deren Bedeutung für die Entwicklung von Nebenwirkungen nach Blutkomponententransfusion in den Mittelpunkt stellen.

\begin{tabular}{ll}
\hline KARGER & @ 2006 S. Karger GmbH, Freiburg \\
Fax +4976145207 14 & Accessible online at: \\
$\begin{array}{l}\text { E-mail Information@Karger.de } \\
\text { www.karger.com }\end{array}$ & www.karger.com/tmh
\end{tabular}

Professor Hans Jørgen Nielsen, MD, DMSc,

Department of Surgical Gastroenterology 435 ,

Hvidovre University Hospital,

2650 Hvidovre, Denmark

Tel. +45 3632-2436, Fax -3760

E-mail h.jnielsen@ofir.dk 


\section{Introduction}

It is well established that homologous blood component transfusion is a life-saving therapy, particularly in patients with acute anemia due to trauma, surgery or childbirth. In addition, blood components may also improve quality of life and even prolong the life of certain persons with chronic anemia. Transfused blood components may maintain the overall hemodynamics, lead to optimal tissue oxygenation, and improve blood coagulation capacity. Due to potential presence of contaminating microbial agents in the donor's blood [1-3], blood component safety has been considered for decades. At least in the industrialized part of the world such considerations have led to development of screening procedures to guarantee the safety and quality of blood components for transfusion [4]. At present transmission of microbial contaminants including HIV and hepatitis viruses are limited, and blood components are considered to have optimal safety for transfusions to patients.

\section{Side Effects of Blood Transfusion}

Transfusion of blood components may infrequently lead to acute side effects in $0.5-2 \%$ of cases, including febrile non-hemolytic transfusion reactions, acute hemolytic transfusion reactions, transfusion-related acute lung injury, and graft-versus-host reactions [5, 6]. In addition, transfusion of homologous components should be considered as transplantation with white cells that express various tissue type antigens not compatible with recipient tissue types [7] may even lead to acute leukocytosis [8]. During recent years it has been investigated whether or not white cells in blood components may lead to transferral of donor genetic material to the recipient, a phenomenon well-known from organ transplantation [9] where it leads to impaired protein synthesis and subsequent risks for the recipients [10]. It has been shown that transfusion of male blood to female recipients may lead to y-chromosome accumulation that may last for weeks, months and infrequently even years [11]. Subsequently, it was shown that donor genes could be traced in more than half of a trauma patient cohort receiving blood component transfusion [12]. At present it is not known in detail whether transfusion of donor genes may lead to a long lasting impairment in recipient protein synthesis. However, blood component contamination with viruses that may be related to cancer development, such as cytomegalovirus, Epstein-Barr virus, herpes simplex virus, papillomavirus, $\mathrm{HAV}, \mathrm{HBV}, \mathrm{HCV}$, human parvovirus, etc. [13] might be considered a potential risk for recipients. It has been shown in animal models and in humans that contamination of transfused blood components with cancer-related virus frequently lead to cancer development [14, 15]. Subsequently, a variety of results concerning blood transfusion to patients with benign diseases and long-term risk of development of malignant diseases such as renal cell carcino- ma, non-Hodgkin's lymphoma and various skin cancers have been presented [16-22]. It has to be highlighted, however, that two other publications focusing on blood component transfusion offered to women after childbirth could not show any association between the transfused blood and increased lifetime risk of malignant disease development [23, 24]. In summary, the majority of current results suggest that blood transfusion to patients with transient impaired immune competence due to trauma or major surgery may enhance the lifetime risk to develop certain malignant diseases. However, presumably due to the increased immune tolerance associated with pregnancy, blood transfusion offered after childbirth does not seem to increase the risk of subsequent development of malignant diseases.

\section{Immunomodulation and Postoperative Infectious Complications after Blood Transfusion}

Emerging evidence has led to the overall agreement that blood component transfusion cause recipient immunomodulation with stimulation of certain immune responses and suppression of others, resulting in an impaired immune competence $[25,26]$. Patients with Crohn's disease, patients undergoing organ transplantation and patients with recurrent rheumatoid arthritis may benefit from blood transfusion-induced impaired immune competence [27] while this may be of disadvantage in patients with trauma or undergoing major surgery [28], due to its relation to development of postoperative infectious complications [29-34]. However, the interpretation of the association of blood transfusion and postoperative infectious complications may be complicated because various other factors in addition to blood component transfusion also play significant roles. Thus, at least bacterial contamination, circumstances under which the operations are performed (e.g. acute versus elective operations), the preoperative host immune competence, the nature of the disease (benign or malignant), alcohol and tobacco abuse are factors that might be considered [28]. There are considerable differences in bacterial contamination between large bowel and hip or knee joint replacement surgery, with a higher risk of infectious complications among patients undergoing surgery for large bowel diseases. Furthermore, patients undergoing emergency surgery for large bowel diseases may have a much higher risk of subsequent infectious complications than patients undergoing elective operations for similar diseases [28]. Finally, there is emerging evidence suggesting that patients with malignant diseases have pronounced impairment of immune competence before, during and after surgery compared with patients with benign disease of the same organ [28, 35]. Therefore, the awareness of the association of blood component transfusion with increased risk of postoperative infectious complications should be differentiated and related to the specific surgical situation. 
Table 1. White cell- and platelet-derived bioactive substances

\begin{tabular}{lll}
\hline Cell type & Bioactive substance & Target \\
\hline Basophils & histamine, serotonin, tryptase, plasminogen activator, peroxidase, & immunomodulation, inflammation, cancer growth \\
Eosinophils & eosinophil protein X, cationic protein, peroxidase, basic protein & inflammation, tissue damage, cancer growth \\
Neutrophils & $\begin{array}{l}\text { myeloperoxidase, YKL-40, elastase, vascular endothelial growth } \\
\text { factor, vascular endothelial growth factor receptor-1, } \\
\text { matrix metalloproteinases }\end{array}$ & $\begin{array}{l}\text { inflammation, tissue damage, hyperpermeability, cancer } \\
\text { growth, cancer invasion and cancer dissemination }\end{array}$ \\
Platelets & $\begin{array}{l}\text { plasminogen activator inhibitor-1, tissue inhibitor of } \\
\text { metalloproteinases-1, vascular endothelial growth factor, tissue factor }\end{array}$ & $\begin{array}{l}\text { inflammation, hyperpermeability, hypercoagulation, } \\
\text { apoptosis inhibition, cancer growth, cancer invasion, } \\
\text { cancer dissemination }\end{array}$ \\
\hline
\end{tabular}

The debate concerning the association between perioperative blood component transfusion and reduced recurrence-free and long-term survival of patients with solid tumors has been running for decades without a final consensus. As shown by retrospective and prospective observational studies, it is well recognized that patients undergoing intended curative resection for colorectal cancer who are perioperatively in need for blood component transfusion have a worse prognosis than patients undergoing similar operations without receiving transfusion $[26,36]$. However, results from clinical studies of patients with various other solid tumors are more difficult to be used in an overall evaluation of the significance of blood component transfusion and poor survival after intended curative surgery. In some of these studies, including breast, esophageal, liver, lung and head and neck cancer, such an association has been shown while in other studies including breast, lung, brain and gynecologic cancer, it could not be confirmed. A variety of important factors and the specific biology of a certain malignant disease may play a significant role for the recurrence risk after intended curative operation. Thus, hereditary or acquired genetic polymorphisms, presence of minimal residual disease including micrometastases, tumor location within a specific organ, acute operation as well as the level of surgeon education and training are parameters that also should be included as significant determinants of recurrent disease and long-term survival [37-40]. Due to release of cancer growthrelated substances in inflammation and infection, development of postoperative infectious complications might be included as an additional parameter influencing the long-term outcome of cancer patients. Considering the variety of solid malignant diseases included in the evaluation of the negative survival impact of blood component transfusion, at least three cancerous diseases - colorectal cancer, esophageal cancer, and head and neck cancer - are known to be associated with a relative high risk of developing postoperative infectious complications. Recent results from a major clinically controlled, prospective observational study including 740 patients undergoing elective resection for colorectal cancer showed that patients receiving perioperative blood component transfusion and who subsequently developed postoperative infectious complications $(\mathrm{n}=134)$ had a significant and stage-independent reduced recurrence-free and long-term survival [41]. It should be noted that patients receiving blood transfusion ( $\mathrm{n}=296$ ) without subsequent development of postoperative infectious complications had a prognosis similar to non-transfused patients. These findings confirm previous studies and are confirmed by subsequent studies [42-44], indicating that postoperative infectious complications play an important, additional role for the prognosis of cancer patients. In summary, variations in the studies evaluating the effect of blood component transfusion on prognosis after resection for a malignant disease may explain some of the discrepancies between previous and current results. Perioperative blood component transfusion may play a role in reducing the prognosis in some patients, in particular in those with gastrointestinal and head and neck tumors, while it does not have a pronounced effect on patients with a variety of other tumors.

\section{Autologous Transfusion - a Step Forward?}

Due to e.g. the risk of transmission of virus from donor to recipient, postoperative infectious complications, cancer recurrence, microchimerism, and exposure to foreign tissue type antigens by transfusion of homologous components, preoperative autologous blood deposition has been introduced in most European countries. In elective surgery for benign diseases including hip and knee replacement surgery this approach has reduced the overall infectious complication rates significantly [45]. In surgery for solid, malignant tumors, however, results from studies comparing homologous blood component transfusion with predeposit autologous blood transfusion indicate that patients receiving autologous blood have a similar poor prognosis as patients receiving homologous blood [46]. While blood donation does not adversely affect the immune competence of healthy blood donors, blood donation in patients with malignant diseases lead to impaired immune competence that may play a negative role for the patients during and after 
surgery [27]. This may partially explain why patients receiving their own predeposit blood have a similar poor prognosis as those patients receiving homologous blood component transfusion.

It is indicated, at least in patients with malignant diseases, that side effects to blood component transfusion using homologous or autologous blood components may be similar. One explanation for this phenomenon may be the presence of white cells and platelets in the blood components. Various white cell- and platelet-derived bioactive substances well known as being involved in posttrauma complications, immunomodulation, development of infectious complications, and cancer cell growth, invasion and dissemination are stored in granules of white cells and platelets (table 1).

These substances have been shown to accumulate during preparation and storage of various blood components for transfusion in which white cells and platelets are present [47-50]. During storage the substances accumulate in a storage time-dependent manner, and the concentrations may increase by a factor of 65-70 for selected substances in whole blood components. The final concentration in a blood component may vary with the length of storage, ranging from 35 days in Scandinavia to 49 days in various other European countries for red cell components. Such factors should be considered to play an additional role in the development of posttransfusion side effects - particularly because results from experimental studies suggests that bioactive substances in blood components are associated with the side effects of blood [51, 52]. In addition, emerging evidence suggested that side effects to red cell blood component transfusion are associated with storage time of the components [53-58]. Such results may change the procedure for evaluation of side effects to blood component transfusion, and future prospective studies should include storage time as an independent and important parameter. Moreover, blood preparation and storage should be reconsidered as results from a variety of clinical prospective observational studies suggest that leukocyte filtration may be of benefit for the majority of trauma and surgical patients [59-62] to reduce various posttrauma complications. While the evidence for a benefit of leukofiltration is supported by results from a variety of specific surgical areas, including intraabdominal, cardiac, and hip replacement surgery, the benefit of leukofiltration of blood components transfused to cancer patients seem more diverging [63-65]. Obviously leukofiltration does not seem to have any beneficial effect on long-term survival of patients resected for colorectal cancer. The optimal timing of leukofiltration has been considered in various in vitro studies. It is suggested that prestorage leukofiltration, by avoiding accumulation of bioactive substances during storage of blood components, is superior to bedside leukofiltration. Bedside filtration performed at the time of transfusion will not inhibit bioactive substance release and accumulation during storage of blood from the time of donation and storage until the time of transfusion [66, 67]. This suggestion has been further under- lined by experimental results showing blood component transfusion-associated, impaired immune reaction [67-69] and in vitro cancer cell growth stimulation [70] being attenuated by prestorage leukofiltration, while bedside leukofiltration appears to have no beneficial effect compared with non-filtered blood components. The introduction of universal leukocyte filtration in the majority of European countries at first sight increased the economic requirements, but the current reduction of the frequency of blood component transfusion-associated side effects may in the long run be of benefit for the patients and certainly for the economic capability as well. Subsequent change in the transfusion strategy aiming at reducing the 'overuse' of blood components, as shown by a European Community survey of blood usage at 43 university hospitals [71], may per se be of additional benefit for a variety of patients. Results from large multiinstitutional and multinational studies suggest that blood component transfusion can be substantially reduced with benefit for the patients [72-75]. In summary, introduction of universal prestorage leukofiltration is recommended to avoid side effects related to preparation- and storage-associated accumulation of white cell- and platelet-derived bioactive substances. But simultaneous reduction of the 'overuse' of blood components must be an additional requirement.

It should be considered that transfusion with homologous and predeposit autologous blood components may lead to similar side effects, due to mechanisms that cannot be explained by the well-known blood transfusion-associated immunomodulation. In particular, the relation between blood transfusion-associated development of postoperative infectious complications in patients operated for malignant diseases and subsequent poor prognosis should be reconsidered. Evidence has appeared that suggests blood transfusion per se to be without relation to poor prognosis in cancer surgery while the combination of blood component transfusion and development of postoperative infectious complications seems to be related to poor prognosis. The mechanisms are at present not known in detail but might be related to accumulation of bioactive substances in the blood components, release of similar bioactive substances in the patient due to bacterial contamination, and genetic polymorphisms in various parts of the immune system. In particular, polymorphisms in mannose binding lectin (MBL) genes, which is a prominent part of the innate immune system, may play a significant role in the development of postoperative bacterial infectious complications and resistance to cancer growth after resection for colorectal cancer [76, 77]. $10-15 \%$ of Caucasians have polymorphisms in the MBL genes, and such persons may be at risk during chemotherapy, trauma, major surgery and blood component transfusion where transient impairment of the overall immune competence is introduced $[78,79]$. Future studies may be directed to explore the combination of genetic polymorphisms, blood component transfusion, infectious complications and longterm survival after resection for cancer. 


\section{References}

1 Busch MP: Testing blood donors for HIV: current controversies. Immunol Invest 1995;24:147-54.

$\checkmark 2$ Tattevin P, Cremieux AC, Descamps D, Carbon C: Transfusion-related infectious mononucleosis. Scand J Infect Dis 2002;34:777-8.

3 Busch MP, Kleinman SH, Nemo GJ: Current and emerging infectious risks of blood transfusions. JAMA 2003;289:959-62.

4 Busch MP, Glynn SA, Stramer SL, Strong DM, Caglioti S, Wright DJ, Pappalardo B, Kleinman SH A new strategy for estimating risks of transfusiontransmitted viral infections based on rates of detection of recently infected donors. Transfusion 2005; 45:254-64.

$\checkmark 5$ Domen RE: An overview of immune hemolytic anemias. Cleve Clin J Med 1998;65:89-99.

6 Bux J: Transfusion-related acute lung injury (TRALI): a serious adverse event of blood transfusion. Vox Sang 2005;89:1-10.

7 Nusbacher J: Blood transfusion is mononuclear cell transplantation. Transfusion 1994;34:1002-6.

8 Izbicki G, Rudensky B, Na'amad M, Hershko C, Huerta M, Hersch M: Transfusion-related leukocytosis in critically ill patients. Crit Care Med 2004;32: $439-42$.

9 Olszewski WL, Interewicz B, Maksymowicz M, Stanislawska J: Transplantation of organs is transplantations of donor DNA: fate of DNA disseminated in recipient. Transpl Int 2005;18:412-8.

10 Bouwman LH, Roos A, Terpstra OT, de Knijff P, van Hoek B, Verspaget HW, Berger SP, Daha MR, Frolich M, van der Slik AR, Doxiadis Jr, Roep BO, Schaapherder AF: Mannose binding lectin gene polymorphisms confer a major risk for severe infections after liver transplantation. Gastroenterology 2005;129:408-14.

11 Lee TH, Paglieroni T, Ohto H, Holland PV, Busch MP: Survival of donor leukocyte subpopulations in immunocompetent transfusion recipients: frequent long-term microchimerism in severe trauma patients. Blood 1999;93:3127-39.

12 Utter GH, Owings JT, Lee TH, Paglieroni TG, Reed WF, Gosselin RC, Holland PV, Busch MP: Blood transfusion is associated with donor leukocyte microchimerism in trauma patients. J Trauma 2004:57:702-8.

13 Busch MP, Lee TH: Role of donor leukocytes and leukodepletion in transfusion-associated viral infections; in Sweeney J, Heaton WA (eds): Clinical Benefits of Leukodepletet Blood Products. Austin, Landers, 1995, pp 97-102.

14 Mosier DE, Baird SM, Kirven MB, Gulizia RJ, Wilson DB, Kunayashi R, Picchio G, Garnier JL, Sullivan JL, Kipps TJ: EBV-associated B-cell lymphomas following transfer of severe human peripheral blood lymphocytes to mice with severe combined immune deficiency. Curr Top Microbiol Immunol 1990;166:317-23.

15 Di Bisceglie AM, Simpson LH, Lotze MT, Hoofnagle JH: Development of hepatocellular carcinoma among patients with chronic liver disease due to hepatitis C viral infection. J Clin Gastroenterol 1994:19:222-6.

16 Blomberg J, Möller T, Olsson H, Anderson H, Jonsson M: Cancer morbidity in blood recipients - results of a cohort study. Eur J Cancer 1993;29A: 2101-5.

17 Memon A, Doll R: A search for unknown bloodborne oncogenic viruses. Int J Cancer 1994;58: 366-8.
8 Brandt L, Brandt J, Olsson H, Anderson H, Möller $\mathrm{T}$ : Blood transfusion as a risk factor for nonHodgkin lymphoma. Br J Cancer 1996;73:1148-51.

19 Cerhan JR, Wallace RB, Folsom AR, Potter JD, Sellers TA, Zheng W, Lutz CT: Medical history risk factors for non-Hodgkin's lymphoma in older women. J Natl Cancer Inst 1997;89:314-8

20 Adami J, Nyren O, Bergström R, Ekbom A, McLaughlin JK, Hogman C, Fraumeri JF, Glimelius B: Blood transfusion and non-Hodgkin lymphoma: lack of association. Ann Intern Med 1997; 127:365-71.

21 Vamvakas EC: Allogeneic blood transfusion as a risk factor for the subsequent development of nonHodgkin's lymphoma. Transfus Med Rev 2000;14: 258-68.

22 Cerhan JR, Wallace RB, Dick F, Kemp J, Parker AS, Zheng W, Sellers TA, Folsom AR: Blood transfusions and risk of non-Hodgkin's lymphoma sub types and chronic lymphocytic leukaemia. Cancer Epidemiol Biomarkers Prev 2001;10:361-8.

23 Anderson H, Brandt L, Ericson A, Olsson H, Möller T: Blood transfusion at delivery and risk of subsequent malignant lymphoma in the mother. Vox Sang 1998;75:145-8.

24 Skanberg J, Frisk B: Blood transfusion does not influence the development of malignant tumours Eur J Surg 1999;165:528-34.

25 Blajchman MA: Transfusion immunomodulation or TRIM: what does it mean clinically? Hematology 2005;10(suppl 1):208-14.

26 Mynster T: Blood transfusion-induced immunomodulation - is storage time important? Thesis. Dan Med Bull 2003;50:368-84.

27 Nielsen HJ: Clinical impact of bioactive substances in blood components: Implications for leukocyte filtration. Infusionther Transfusionmed 1998;25: 296-304.

28 Nielsen HJ: The effect of histamine type-2 receptor antagonists on posttraumatic immune competence. Thesis. Dan Med Bull 1995;42:162-74.

29 Carson JL, Altman DG, Duff A, Noveck H, Weinstein MP, Sonnenberg FA, Hudson JI, Provenzano G: Risk of bacterial infection associated with allogeneic blood transfusion among patients undergoing hip fracture repair. Transfusion 1999;39: 694-700.

30 Chang H, Hall GA, Geerts WH, Greenwood C, McLeod RS, Sher GD: Allogeneic red blood cell transfusion is an independent risk factor for the development of postoperative bacterial infection. Vox Sang 2000;78:13-8

31 Taylor RW, Manganaro L, O'Brian J, Trottier SJ, Parkar N, Veremakis C: Impact of allogeneic packed red blood cell transfusion on nosocomial in fection rates in the critically ill patient. Crit Care Med 2002;30:2249-54

32 Claridge JA, Sawyer RG, Schulman Am, McLemore EC, Young JS: Blood transfusions correlate with infections in trauma patients in a dosedependent manner. Am Surg 2002;68:566-72.

33 Malone DL, Dunne J, Tracy JK, Putman AT, Scalea TM, Napolitano LM: Blood transfusion, independent of shock severity, is associated with worse outcome in trauma. J Trauma 2003;54:898-907.

34 Hill GE, Frawley WH, Griffith KE, Forester JE, Minei JP: Allogeneic blood transfusion increases the risk of postoperative bacterial infection: A meta-analysis. J Trauma 2003;54:908-14.
35 Hammer JH, Basse L, Werther K, Svendsen MN, Brünner N, Christensen IJ, Nielsen HJ. Impact of elective resection on plasma TIMP-1 levels in patients with colorectal cancer. Colorectal Dis 2006; 8:168-72.

36 Amato AC, Pescatori M: Effect of perioperative blood transfusions on recurrence of colorectal cancer. Meta-analysis stratified on risk factors. Dis Colon Rectum 1998;41:570-85.

37 Oda S, Zhao Y, Maehara Y: Microsatellite instability in gastrointestinal cancers: abrief update. Surg Today 2005;35:1005-15.

38 Pantel K, Woelfle U: Detection and molecular characterisation of disseminated tumour cells: im plications for anti-cancer therapy. Biochim Biophys Acta 2005;1756:53-64.

39 McArdle CS, Hole D: Impact of variability among surgeons on postoperative morbidity and mortality and ultimate survival. BMJ 1991;302:1501-5.

40 McArdle CS, Hole DJ: Emergency presentation of colorectal cancer is associated with poor 5-year survival. Br J Surg 2004;91:605-9.

41 Mynster T, Christensen IJ, Moesgaard F, Nielsen HJ: Effects of the combination of blood transfusion and postoperative infectious complications on prognosis after surgery for colorectal cancer. Br J Surg 2000;87:1553-62.

42 Grandis JR, Snyderman CH, Johnsen JT, Yu VL, D'Amico F: Postoperative wound infection. A poor prognostic sign for patients with head and neck cancer. Cancer 1992;70:2166-70.

43 Sturgis EM, Congdon DJ, Mather FJ, Miller RH Perioperative transfusion, postoperative infection, and recurrence of head and neck cancer. South Med J 1997;90:1217-24.

44 Kressner U, Graf W, Mehteme H, Påhlman L, Glimelius B: Septic complications and prognosis after surgery for rectal cancer. Dis Colon Rectum 2002;45:316-21.

45 Innerhofer P, Klingler A, Klimmer C, Fries D, Nussbaumer W: Risk for postoperative infection after blood transfusion of white blood cell-filtered allogeneic or autologous blood components in orthopedic patients undergoing primary arthroplasty. Transfusion 2005;45:103-10.

46 Busch OR, Hop WCJ, Hoynck van Papendrech MAW, Marquet RL, Jeekel J: Blood transfusion and prognosis in colorectal cancer. N Engl J Med 1993;328:1372-6.

47 Nielsen HJ, Reimert CM, Pedersen AN, Brünner N, Edvardsen L, Dybkjaer E, Kehlet H, Skov PS: Time-dependent, spontaneous release of white celland platelet-derived bioactive substances from stored human blood. Transfusion 1996;36:900-5.

48 Nielsen HJ, Reimert C, Pedersen AN, Dybkjaer E, Brünner N, Alsbjorn B, Skov PS: Leucocyte-derived bioactive substances in fresh frozen plasma. Br J Anaesth 1997;78:548-52.

49 Edvardsen L, Taaning E, Drachmann O, Mynster T, Nielsen HJ: Accumulation of bioactive substances during storage of various platelet components. Am J Hematol 2001;67:157-62.

50 Nielsen HJ, Werther K, Mynster T, Brünner N: Soluble vascular endothelial growth factor in various blood transfusion components. Transfusion 1999;39: 1078-83.

51 Biedler AE, Schneider SO, Seyfert U, Rensing H, Grenner S, Gimdt M, Bauer I, Bauer M: Impact of alloantigens and storage-associated factors on stimulated cytokine response in an in vitro model of blood transfusion. Anesthesiology 2002;97:1002-9. 
52 Patel HB, Nasir FA, Nash GF, Scully MF, Kakkar AK: Enhanced angiogenesis following allogeneic blood transfusion. Clin Lab Haematol 2004;26: 129-35.

53 Purdy FR, Tweeddale MA, Merrick PM: Association of mortality with age of blood transfused in septic ICU patients. Can J Anaesth 1997;44: 1256-61.

54 Vamvakas EC, Carven JH: Transfusion and postoperative pneumonia in coronary artery bypass graft surgery: effect of the length of storage of transfused red cells. Transfusion 1999;39:701-10.

- 55 Zallen G, Offner PJ, Moore EE, Blackwell J, Ciesla DJ, Gabriel J, Denney C, Silliman CC: Age of transfused blood is an independent risk factor for postinjury multiple organ failure. Am J Surg 1999; 178:570-2.

56 Mynster T, Nielsen HJ: The impact of storage time of transfused blood on postoperative infectious complications in rectal cancer surgery. Scand J Gastroenterol 2000;35:212-7.

57 Offner PJ, Moore EE, Biffl WL, Johnson JL, Silliman CC: Increased rate of infection associated with transfusion of old blood after severe injury. Arch Surg 2002;137:711-7.

-58 Keller ME, Jean R, LaMorte WW, Millham F, Hirsch E: Effects of age of transfused blood on length of stay in trauma patients: a preliminary report. J Trauma 2002;53:1023-5.

59 Nielsen HJ, Hammer JH, Krarup AL, Nielsen LM, Reimert CM, Pedersen AN, Dybkjær E, Partoft S, Alsbjørn B: Prestorage leucocyte filtration may reduce leucocyte-derived bioactive substance accumulation in patients operated for burn trauma. Burns 1999;25:162-170.

60 Hebert PC, Fergusson D, Blajchman MA, Wells GA, Kmetic A, Coyle D, Heddle N, Germain M, Goldman M, Toye B, Schweitzer I, van Wakraven C, Devine D, Sher GD: Clinical outcomes following institution of the Canadian universal leukoreduction program for red blood cell transfusions. JAMA 2003;289:1941-9.

61 van Hilten JA, van de Watering LMG, van Bockel JH, van de Velde CJH, Kivit J, Brand R, van den Hout WB, Geelkerken RH, Roumen RMH, Wesselink RMJ, Koopman-van Gemert AW, Koning J, Brand A: Effects of transfusion with red cells filtered to remove leucocytes: randomised controlled trial in patients undergoing major surgery. BMJ 2004:328:1281-9.
62 Fergusson D, Khanna MP, Tinmouth A, Hebert PC: Transfusion of leukoreduced red blood cells may decrease postoperative infections: two meta-analyses of randomized controlled trials. Can J Anaesth 2004;51:417-24.

63 Houbiers JG, Brand A, van de Watering LM, Hermans J, Verwey PJ, Bijnen AB, Pahlplatz P, Eeftinck Schattenkerk M, Wobbes T, de Vries JE: Randomised controlled trial comparing transfusion of leucocyte-depleted or buffy-coat-depleted blood in surgery for colorectal cancer. Lancet 1994;344: $573-8$

64 van de Watering LM, Brand A, Houbiers JG, Klein Kranenbarg WM, Hermans J, van de Velde C: Perioperative blood transfusions, with or without allogeneic leucocytes, relate to survival, not to cancer recurrence. Br J Surg 2001;88:267-72.

65 Jensen LS, Puho E, Pedersen L, Mortensen FV, Sørensen HT: Long-term survival after colorectal surgery associated with buffy-coat-poor and leukocyte-depleted blood transfusion: a follow-up study. Lancet 2005;365:681-2.

66 Hammer JH, Mynster T, Reimert CM, Brünner N, Nielsen HJ: Reduction of bioactive substances in donor blood. Prestorage versus bedside leucofiltration. Eur J Haematol 1999;63:29-34.

67 Mynster T, Hammer JH, Nielsen HJ: Prestorage and bedside leucofiltration of whole blood modulates storage time dependent suppression of in vitro TNF release. Br J Haematol 1999;106:248-51.

68 Nielsen HJ, Werther K, Mynster T, Svendsen MN, Rosendahl S, Elley T, Skov F: Bacteria-induced release of white cell- and platelet-derived vascular endothelial growth factor in vitro. Vox Sang 2001; 80:170-8.

69 Hammer JH, Mynster T, Reimert CM, Brünner N, Skov F, Nielsen HJ: Bacteria-induced release of white cell- and platelet-derived bioactive substances in vitro. Int J Gastrointest Cancer 2003;31: 165-79.

70 Bordin JO, Bardossy L, Blajchman MA: Growth enhancement of established tumors by allogeneic blood transfusion in experimental animals and its amelioration by leukodepletion. Blood 1994;84: 344-8.
71 Sirchia G, Giovanetti AM, McClelland B, Fracchia GN: Safe and Good Use of Blood in Surgery (SANGUIS). Use of Blood and Artificial Colloids in 43 European Hospitals. Strasbourg, Council of Europe Publishing 1994, pp 1-235.

72 Carson JL, Duff A, Berlin JA, Lawrence VA, Poses RM, Huber EC, O'Hara DA, Noveck H, Strom BL: Perioperative blood transfusion and postoperative mortality. JAMA 1998;279:199-205.

73 Hebert PC, Wells G, Blajchman MA, Marshall J, Martin C, Pagliarello G, Tweeddale M, Schweitzer I, Yetisir E: A multicenter, randomized, controlled clinical trial of transfusion requirements in critical care. N Engl J Med 1999;340:409-17.

74 Vincent LJ, Baron JF, Reinhart K, Gattinoni L, Thijs L, Webb A, Meier-Hellmann A, Nollet G Pers-Bota D: Anemia and blood transfusion in critically ill patients. JAMA 2002;288:1499-507.

75 Poon RT, FAN ST, Lo CM, Liu CL, Yuen WK, Yeung $\mathrm{C}$, Wu J: Improving perioperative outcome expands the role of hepatotectomy in management of benign and malignant hepatobiliary diseases: analysis of 1222 consecutive patients from a prospective data set. Ann Surg 2004;240:698-708.

76 Ytting H, Jensenius JC, Thiel S, Christensen IJ, Nielsen HJ: Increased activity of the MBL pathway in patients with colorectal cancer. Scand J Gastroenterol 2004;39:674-9.

77 Ytting H, Christensen IJ, Jensenius JC, Thiel S, Nielsen HJ: Preoperative mannan-binding lectin pathway and prognosis in colorectal cancer. Cancer Immunol Immunother 2005:54:265-72.

78 Gomi K, Tokue Y, Kobayashi T, Takahashi H, Watanabe A, Fujita T, Nukiwa T: Mannose-binding lectin gene polymorphism is a modulating factor in repeated respiratory infections. Chest 2004;126: 95-9.

79 Thiel S, Frederiksen PD, Jensenius JC: Clinical manifestations of mannan-binding lectin deficiency Mol Immunol 2006;43:86-96. 